\title{
PURE RED CELL ANAEMIA COINCIDENT WITH BENIGN THYMOMA
}

\author{
BY \\ F. KURREIN \\ From the Department of Pathology, Royal Infirmary, Worcester
}

(RECEIVED FOR PUBLICATION NOVEMBER 12, 1958)

Pure red cell agenesis in adults was first described by Kaznelson (1922). Since then the condition has been seen with and without coincident thymic tumour, and by March, 1958, 14 cases of the tumour-anaemia syndrome had been reported (Davidsohn, 1941 ; Humphreys and Southworth, 1945 ; Chediak, Fuste, and Rosales, 1953 ; Ross, Finch, Street, and Strieder, 1954 ; Chalmers and Boheimer, 1954 ; Bakker, 1954 ; Stibbe, 1955 ; Weinbaum and Thompson, 1955; Ramos and Loeb, 1956; Bayrd and Bernatz, 1957 ; Mielke, 1957).

In view of the comparative rarity and the numerous problems posed by this condition publication of another single case seems justified.

Mrs. L. W., aged 70, was first seen in September, 1954, when she was referred to the chest clinic for investigation of persistent purulent bronchitis. Chest radiographs showed a midline retrosternal mass about $7 \mathrm{~cm}$. in diameter. Tomography and bronchoscopy before and after the induction of a pneumothorax confirmed the extrapulmonary site of the mass. As the possibility of malignancy could not be ruled out surgery was offered, but the patient refused operation. A blood count at this time showed a haemoglobin of 11.7 g. $\%$, and 16,000 white cells per c.mm. The stained film presented a normal picture.

The patient was kept under observation, attending at three-monthly intervals. Eight sets of radiographs taken over two years failed to show any change in the retrosternal mass. Mrs. W.'s clinical state varied only with the relapses in the bronchitis, which were controlled by courses of terramycin. On her last out-patient attendance (September 24, 1956) she had a little white sputum, but looked and felt well.

On November 22 she was admitted with a history of severe dyspnoea, palpitations, and swelling of the legs coming on in the last few weeks. Furthermore, her urine had become thick and foul smelling.

Examination showed her to be grossly anaemic, slightly cyanosed, and dyspnoeic on movement. Apart from a few rales in the chest and the swelling of the legs there were no abnormal physical signs (blood pressure $150 / 70 \mathrm{~mm}$. $\mathrm{Hg}$ ).
Investigation centred on the anaemia. Haemoglobin was $4.5 \mathrm{~g} . \%$ with normal-looking cells in the stained film. White cells numbered 14,500 per c.mm. The correct diagnosis was suggested by the bone marrow films, which showed only one erythroblast, and that dubious, in a count of 1,000 nucleated cells. Megakaryocytes and the entire white cell series looked normal. In addition there were fair numbers of small, dense, "lymphoid" cells (Fig. 1) similar to those described in previous cases (Chalmers and Boheimer, 1954 ; Bayrd and Bernatz, 1957). Repeated reticulocyte counts failed to produce any evidence of red cell regeneration. Serum bilirubin was $1 \mathrm{mg} . \%$, the direct and indirect Coombs tests were negative. No agglutinins could be found in normal and acidified serum. Gastric content analysis showed a low free acid curve. No free or occult blood was

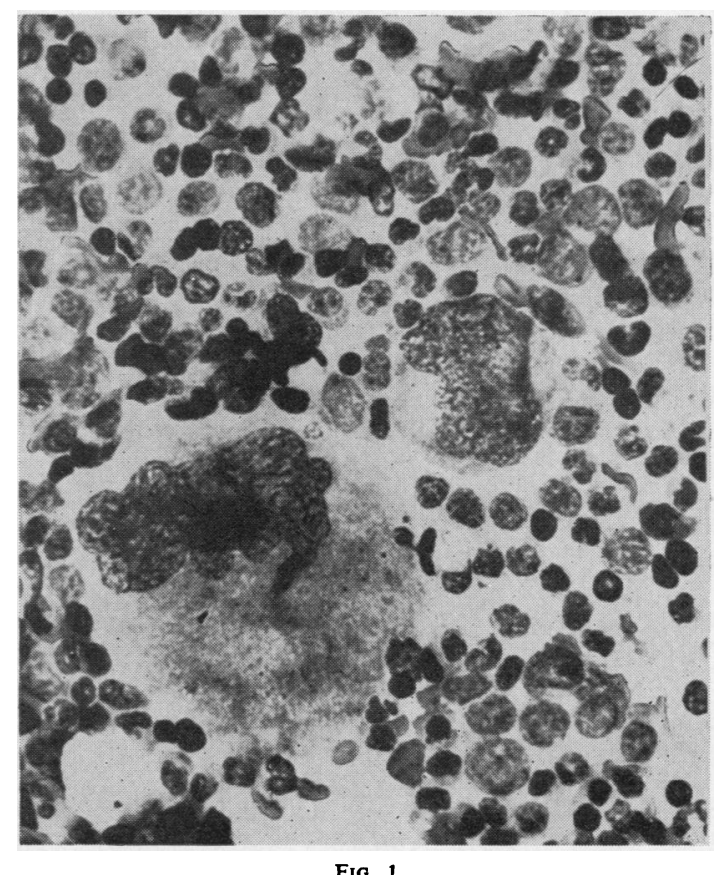




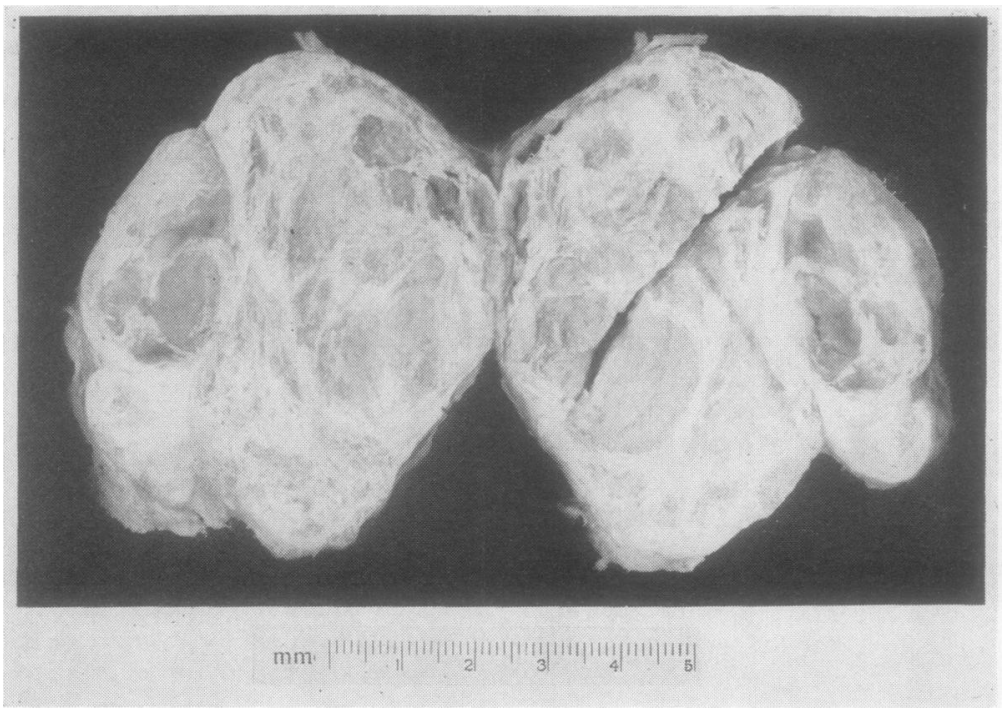

FIG. 2

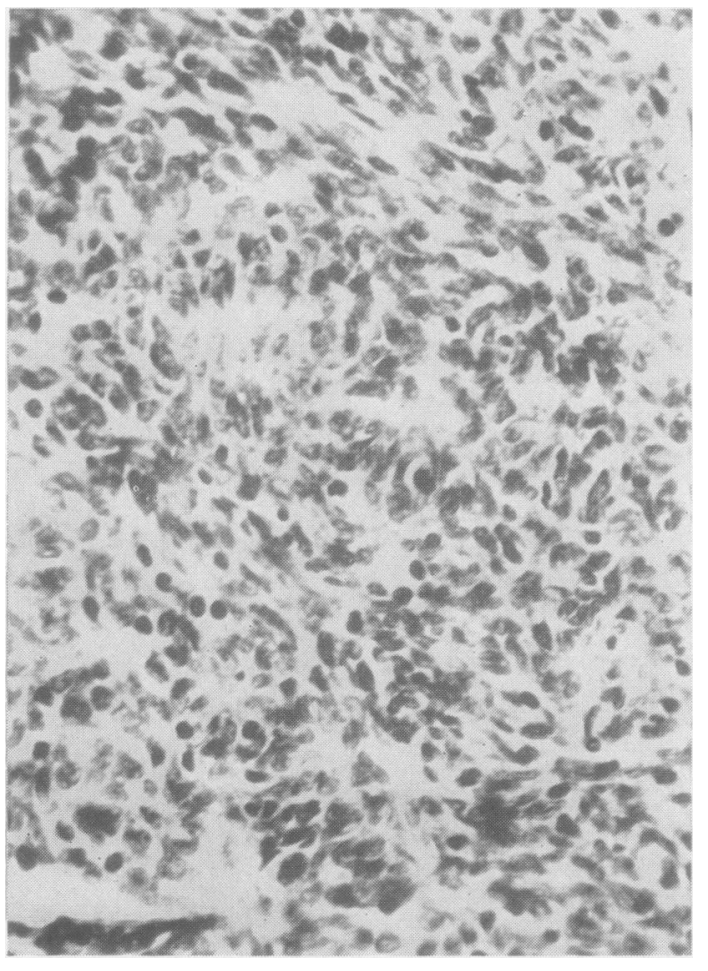

Fig. 3

$\times 300$.

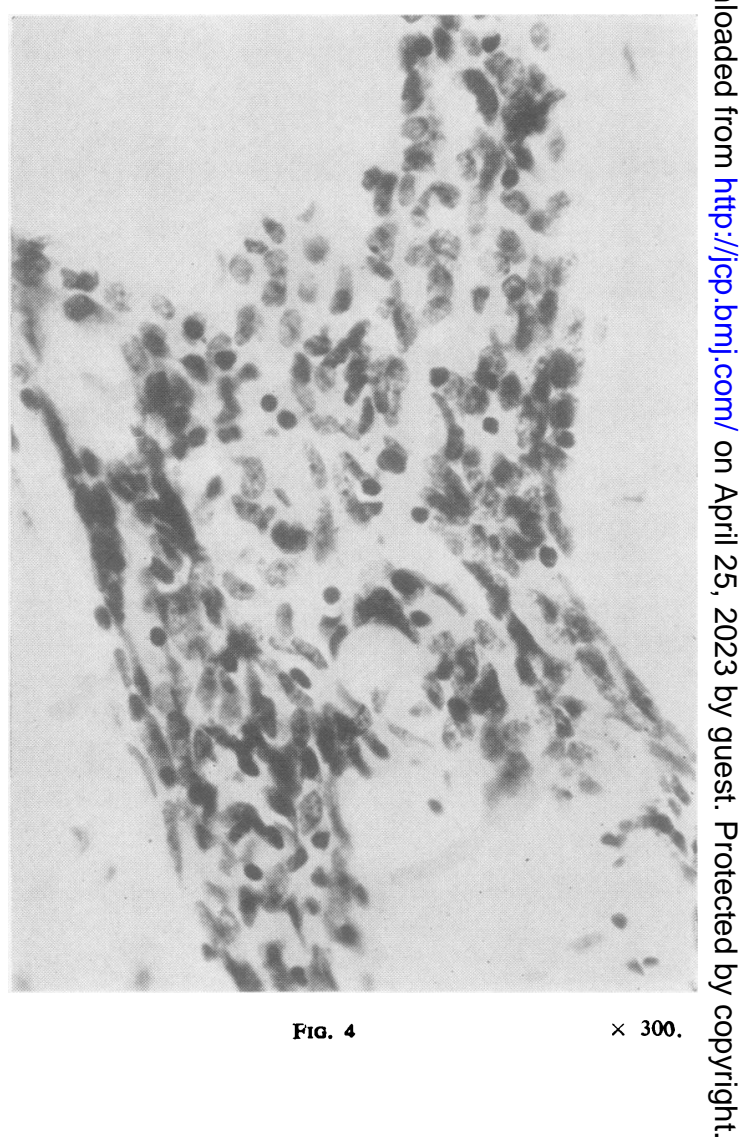


demonstrated in faeces or gastric juice. Repeated urine cultures confirmed infection by $B$. proteus and a coliform bacillus.

The results of blood counts during the last two years are tabulated below:

\begin{tabular}{c|c|c|c|c}
\hline Date & $\begin{array}{c}\text { Hb } \\
(\mathrm{g} . \%)\end{array}$ & $\begin{array}{c}\text { W.B.C. } \\
\text { per c.mm. }\end{array}$ & $\begin{array}{c}\text { E.S.R. } \\
\text { (Westergren) }\end{array}$ & $\begin{array}{c}\text { Morphology in } \\
\text { Stained Film }\end{array}$ \\
\cline { 1 - 2 } $13 / 9 / 54$ & $11 \cdot 7$ & 16,000 & 40 & Normal \\
$26 / 1154$ & 14.5 & 7,000 & 5 &, \\
$18 / 4 / 55$ & 14.8 & 12,000 & 51 &, \\
$21 / 1156$ & 4.5 & 14,500 & &, \\
$3 / 1 / 57$ & 3.5 & 31,000 & &, \\
\hline
\end{tabular}

In the four weeks after admission the anaemia was treated with 4 pints of whole blood and $2,450 \mathrm{mg}$. of cortisone. Transfusions were kept to a minimum because of respiratory embarrassment due to the exacerbated bronchitis. A repeat bone marrow examination at this time showed unchanged appearances. The respiratory and urinary disease processes proceeded and the patient died on January 4, 1957.

Post-mortem examination on January 7 yielded the following positive findings.

There were old, adherent thrombi in the pulmonary arteries, the left renal vein, and in the pelvic venous plexus, but none in the limb veins. The superior mediastinum contained an encapsulated tumour, weighing $48.5 \mathrm{~g}$. and measuring $7 \times 6 \times 2.5 \mathrm{~cm}$., which shelled out easily from the loose connective tissue and pleural margins (Fig. 2). Externally it was somewhat bossed, while the cut surfaces showed a tan-coloured, firm tissue divided by fibrous septa and areas of calcification. The lungs were patchily adherent to the chest wall and showed tubular bronchiectasis and emphysema. The bone marrow of the sternum, ribs, lumbar vertebrae, and femur was soft, abundant, and greyish-brown. The genitourinary tract presented some simple, uterine fibroids and a severe, chronic cystitis.

The liver was normal in size and shape, weighing $1,200 \mathrm{~g}$. The spleen looked normal and weighed $150 \mathrm{~g}$. Lymph nodes were unremarkable except in the hila of the lung, where they showed oedema and reactive hyperplasia. The adrenals, pituitary, and thyroid looked normal.

Microscopy of the tumour revealed islands of plump oval or spindle cells with large vesicular nuclei. These cells were arranged in irregularly sized and shaped areas separated by densely hyalinized or calcified collagenous septa. Loose aggregates of small round cells consistent with lymphocytes occurred among the large cell islands. There were also a number of cyst-like structures apparently derived from the oval cells. No bodies resembling Hassall's corpuscles were seen (Figs. 3 and 4). The appearances were those of a benign lymphoepithelioma of the thymus.

Sections of liver and spleen showed a fair amount of iron giving Perls's reaction. No such iron was found in the bone marrow. The tumour did not contain any stainable iron.

\section{Comment}

This case resembles most of the previously reported ones in many or all the relevant features. There was unequivocal evidence of a stationary mediastinal tumour long before the abrupt onset of the anaemia. Here, too, was failure to respond to medical treatment (surgery was contraindicated by the general condition and the age of the patient). No haemolytic or immune mechanism could be demonstrated.

In this instance the process was confined to the red cells without, even at the end, involvement of platelets or leucocytes. Although the patient was old, neither clinically nor at necropsy was there anything to suggest failure or overactivity of any of the known hormone-producing organs. If the thymic tumour was indeed the source of a hormonal influence on the marrow no explanation can be given for its action at the time it occurred, although the tumour was known to be present for at least two years previously.

The cases of Opsahl (1939) and Radojević and Hahn (1935) have been excluded from this review because of the doubtful nature of the thymic tumours, and Matras and Priesel's case (1928) was not a truly proven agenesis.

\section{Summary}

A further fatal case of red cell agenesis coincident with a benign thymoma is reported.

I am indebted to Drs. C. F. Cropper and E. N. Moyes for access to their clinical records. This paper would not have been written without the help and encouragement of Drs. J. N. Marshall Chalmers and $\mathrm{P}$. Kidd. The photomicrographs are by $\mathrm{Mr}$. G. D. Holland.

\section{REFERENCES}

Bakker, P. M. (1954). Ned. T. Geneesk., 98, 386.

Bayrd, E. D., and Bernatz, P. E. (1957). J. Amer. med. Ass., 163, 723. Chalmers, J. N. M., and Boheimer, K. (1954). Brit. med. J., 2, 1514. Chediak, A. B., Fuste, R., and Rosales, G. V. (1953). Arch. Univ. Habana, 5, 27.

Davidsohn, I. (1941). Illinois med. J., 80, 427.

Humphreys, G. H., and Southworth, H. (1945). Amer. J. med. Sci., 210, 501.

Kaznelson, P. (1922). Verh. dtsch. Ges. inn. Med., 34, 557.

Matras, A., and Priesel, A. (1928). Beitr. path. Anat., 80, 270.

Mielke, H. G. (1957). Ärztl. Wschr., 12, 556.

Opsahl, R. (1939). Nord. Med., 2, 1835.

Radojevir, S., and Hahn, A. (1935). Strahlentherapie, 53, 90.

Ramos, A. J., and Loeb, V. (1956). J. Amer. med. Ass., 160, 1317.

Ross, J. F., Finch, S. C., Street, R. B., and Strieder, J. W. (1954). Blood, 9, 935 .

Stibbe, P. D. (1955). Ned. T. Geneesk., 99, 3782.

Weinbaum, J. G. and Thompson, R. F. (1955). Amer. J. clin. Path., 25, 761 . 